\title{
Armando Tonioli
}

A. A. PETERLINI

Abiit, non abest.

I. N. Salum

Q uando o jovem professor de Ciências Físicas e Naturais compareceu, em 1941, à Faculdade de Filosofia, Ciências e Letras da Universidade de São Paulo para tentar um curso superior e se matriculou em Letras Clássicas, porque só esse curso lhe permitia continuar com seu trabalho docente, estava bem longe de supor que viria a tornar-se o primeiro professor brasileiro a responder pela disciplina de Língua e Literatura Latina na USP.

Nascido em São Paulo, Armando Tonioli (1915-1970) fez aí seus estudos, trabalhou e viveu, declarando praticamente uma só profissão: professor. De Ciências, no Colégio Paulistano, de 1938 a 1943; de Latim, ainda no Paulistano, de 1943 a 1955; no Instituto Mackenzie Colégio e Faculdade - de 1950 a 1963; e na FFLCH da USP, de 1944 até sua morte.

De suas pesquisas publicou principalmente sobre Terêncio, em especial a respeito da comédia Os Adelfos, núcleo de sua tese de doutoramento. Embora repetisse inúmeras vezes que não tinha bem como uma tese esse trabalho, é ele hoje muito mais conhecido e utilizado que sua tese de docência, $A$ composifá latina d̀ luz da composifáo grega, a qual, se apresenta pesquisa e importância científica superiores às da primeira - atentas as condiçóes atuais, entre nós, de conhecimentos na área -, tem aproveitamento bem menor na comunidade acadêmica.

Armando Tonioli, o professor, não será esquececido jamais pelos que lhe freqüentaram as aulas, quer na Maria Antonia, quer na Cidade Universitária. Rara a transparência do discurso de comunicador exímio e exato, máximo no que tange à história da língua latina, na fonética e na morfologia. Parecia talhado para as minudências dessa disciplina, na qual, como nos complexos aparelhos eletrônicos de hoje, a mínima falha ou dos componentes ou da sequiência, anula o todo. E as suas traduçóes?! A quem entendesse um pouco de latim admirava sobremaneira ver com que precisáo o professor Tónioli era capaz de traduzir a preceito para o vernáculo certas expressóes latinas. Aluno, de uma feita, ante o surpreendente da acribia com que trouxe para o português uma frase latina, não me contive e the perguntei como o conseguia. Confessou 
que, às vezes, levava nisso tempo, refletindo até que lhe acudisse à mente o termo, a forma portuguesa satisfatória.

Na mesma proporçăo em que era obstinado no exato e no transparente, Armando Tonioli detestava qualquer ostentação à luz do saber. Em extremo honesto, nunca teve receio de não saber, de hábito, na hora; alguma vez, depois, mas sempre respondia a contento.

Respeitoso e grave nos momentos sérios, era difícil igualá-lo na jovialidade, na lhaneza, no deixar à vontade com que entretinha os amigos em conversas, ou na maestria e quase arte em contar uma anedota.

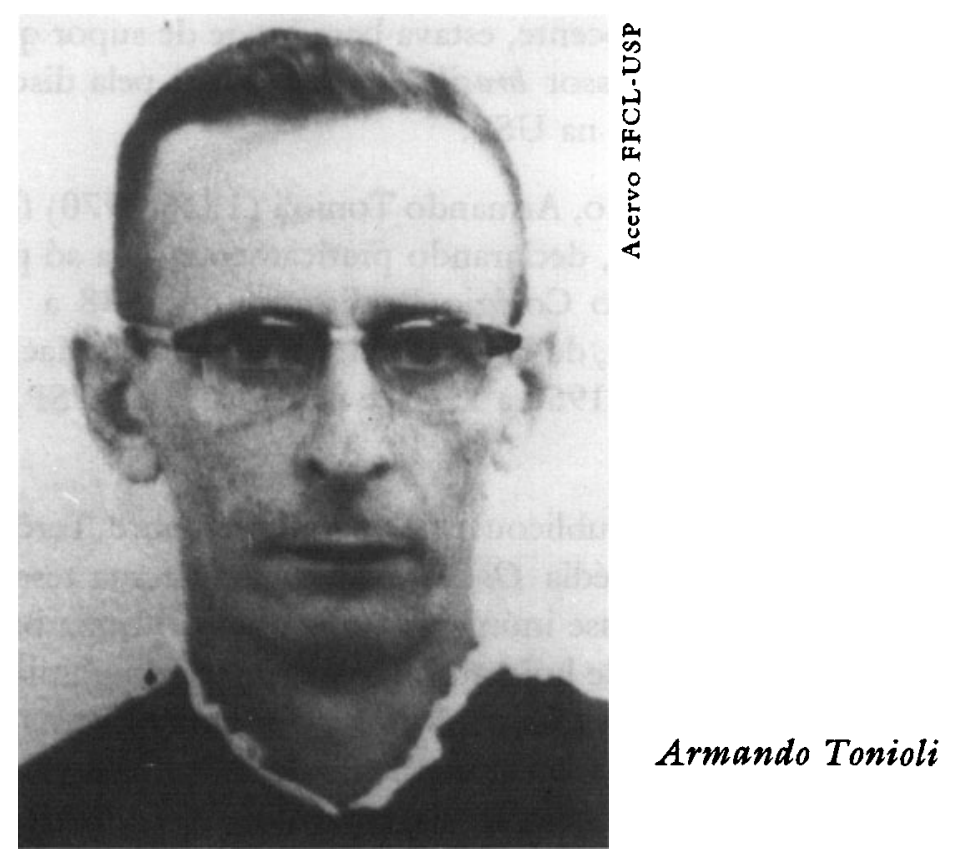

Poucos imaginavam, então, ao ouvi-lo rindo, o lutador responsável que, com 24 anos de idade, quando da morte do pai, entrara a ajudar a mãe na criaçáo do irmão menor de sete anos, como um segundo pai. Chefe de família dedicado, Tonioli criaria ainda os três filhos de seu casamento.

Poderíamos lembrá-lo também como membro de sociedades culturais: Sociedade de Estudos Filológicos; Association Guillaume Budḱ; Associaçáo de Estudos Clássicos do Brasil, de que foi fundador $\mathrm{e}$, mais de uma vez, presidente. Poderíamos relatar o sem-número de bancas examinadoras de que participou, as muitas conferências que fez... Mas nada disso sobrepassaria na memória de seus alunos o professor que, 
herdeiro de toda a formação filológica de seu mestre Urbano Canuto Soares, soube administrar e crescer o legado, para deixá-lo a seus discípulos em aulas inesquecíveis.

Professor Tonioli, ante esse momento de lembrança, como Catulo ao pé do túmulo do irmão, seus alunos lhe deixamos uma saudação e uma saudade: in perpetuum... aue atque uale!

A. A. Peterlini é professor do Departamento de Letras Clássicas e Vernáculas do Departamento de Filosofia, Letras e Ciências Humanas da USP. 